\title{
Intellectual Capital Effectiveness of Jordanian Banks Financial Performance
}

\author{
${ }^{1}$ Abdulaziz Saymeh, ${ }^{2}$ Harbi Arikat, ${ }^{3}$ Firas HaShem, ${ }^{4}$ ASHraf AL-KHALIEH \\ ${ }^{1}$ Middle East University, Amman, JORDAN \\ ${ }^{2}$ Petra Uinversity, Amman, JORDAN \\ ${ }^{3}$ Tafila Technical University, Tafila, JORDAN \\ ${ }^{4}$ Middle East University, Amman, JORDAN
}

\begin{abstract}
Subject research intended to realize the effect of intellectual capital on the outcomes of Jordan's banks listed on Amman Stock Exchange (ASE). Researchers had relyed on Pulic's model to realize the reaserch objectives, the researchers had analyzed the banks' historical financial statements. The study group consisted of all the banks listed on ASE for (2012-2018) period. Researchers had used the descriptive statistics and the basic fundamental analysese tools to mesure the effect of ideological capital as well as financial intelligence on the financial performance of sample banks [1]. This research had revealed a statistically significant positive effect of intellectual capital on the performance of the sample banks represented by the return on assets, while the research indicated that there was no significant effect of intellectual capital on the assets returns of ASE banks.
\end{abstract}

Key Words: Intellectual Capital, Banks Performance, Jordanian Banks, Amman Stock Exchange (AS)

Received: August 13, 2020. Revised: February 28, 2021. Accepted: March 8, 2021.

Published: March 16, 2021.

\section{Introduction:}

At the nineties of the latest century, the concept and importance of intellectual capital began to spread, and recent trends in contemporary management had begun to move towards the countenance of intelligent assets more than physical ones, and thus businessmen had exerted efforts to get a way to make it part of the financial center despite the hardness of measuring it. Financial intelligence had become one of the most important sources for maximizing the value of companies because it stimulates material returns and the ability to survive.

The intellectual capital is represented in the distinct capabilities that exist among some workers, and in light of their possession of these distinct capabilities, experiences and knowledge, they can present new ideas or develop old ideas that give a share in achieving a superior business position, and thus the intellectual capital consists of human capital and structural capital and client capital [2].

Intellectual capital is becoming the basic capital for companies as it manipulates the prime function in the process of regeneration, and it is the leader of the change and creativity processes, and so is able to conform knowledge and value and turn them into competitive advantages, and this is reflected in most developed countries in increasing investment in assets. Intangibles such as 
human resources, research and development, organizational development and relationships that are the basis for generating intellectual capital for most companies [3].

Human capital is a progressively important and essential component of intellectual capital, as it is the engine of knowledge, skills and creativity that the employees possess in the company, in order to create value for the intangible assets represented in the workforce that is characterized by ability, innovation and innovation. Structural capital represents the types of financing that the company adopts to obtain the necessary resources for the continuity and growth of its operations [3].

Client capital is the pillar of human capital as it includes the vision of the company, the quality and technology of the information systems used and their accessibility. It also expresses the organizational structure and depends on the flexibility in the distribution of human capital to the appropriate centers, roles, and responsibilities.

Intellectual capital depends on individuals' abilities, skills and creativity and on innovative thinking, as this leads to the birth of ideas and unconventional solutions to various problems facing business companies, and on providing new solutions and methods that did not exist previously, so it is one of the basic componants of the work environment and is focusing on how to develop its ideological capital is to realize the elements that surpass its competitors, whether it is on the level of product or service goodness or other excellence strategies [4].

As a result of the importance of evaluating the financial performance of companies by investors and users of financial statements in enabling them to determine the success or failure of companies in their investment decisions and plans, measures and indicators for evaluating financial performance have been developed by researchers and those interested in the field of investment and financial analysis, and attention is focused on measuring financial performance from
Through ratios derived from financial statements such as return on assets and equity[5].

\section{Study Aspects}

\subsection{The study Problem and its questions}

Modern administrations usually tend towards an environment that is highly competitive and rapidly changing, so these departments try to keep pace with changes and try to gain an advantage that distinguishes them from other departments.

Therefore, this study came as an attempt to shed light on knowing the importance and effect of intellectual capital on the performance of banks listed on ASE. In this direction, this study had attempted to give an answer the following main question:

Is there an impact of intellectual capital on the financial performance of the banks listed on ASE?

This main question reveals the following subquestions:

1-Was there an impact of human capital on the performance of ASE banks.

2-Was there an effect of structural capital on the performance of ASE banks.

3-Was there an impact of client capital on the financial performance of ASE banks.

\subsection{Study Hypotheses}

This study was designed to examine the effectimpact of intellectual capital on the performance of ASE banks, following were the test hypotheses:

A-The first prime hypothesis HO1: There was no statistically significant impact at a significant level $(\alpha \leq 0.05)$ of intellectual capital on the return on assets in ASE banks.

The first main hypothesis was modified from the following sub-hypotheses: 
HO1-1: There was no statistically significant impact at a significant level $(\alpha \leq 0.05)$ of human capital on the return on assets in ASE banks

HO1-2: There was no statistically significant impact at a significant level $(\alpha \leq 0.05)$ of structural capital on return on assets in ASE banks.

HO1-3: There was no statistically significant effect at a significant level $(\alpha \leq 0.05)$ of client capital on return on assets in ASE banks.

B-The second prime hypothesis, HO2: There was no statistically significant impact at a significant level $(\alpha \leq 0.05)$ of intellecrual capital on return on equity in ASE banks.

The second prime hypothesis was modified from the following sub-hypotheses:

HO2-1: There was no statistically significant impact at a significant level $(\alpha \leq 0.05)$ of human capital on return on equity in ASE banks.

HO2-2: There was no statistically significant impact at a significant level $(\alpha \leq 0.05)$ of structural capital on return on equity in ASE banks.

HO2-3: There was no statistically significant impact at a significant level $(\alpha \leq 0.05)$ of client capital on return on equity in ASE banks.

C-The third main hypothesis, HO3: There was no statistically significant impact at a significant level $(\alpha \leq 0.05)$ of intellectual capital on earnings per share in ASE banks.

The third prime hypothesis was modified from the following sub-hypotheses:

HO3-1: There was no statistically significant impact at a significant level $(\alpha \leq 0.05)$ of human capital on earnings per share in ASE banks.

HO3-2: There was no statistically significant impact at $(\alpha \leq 0.05)$ level of structural capital on earnings per share in ASE banks.
HO3-3: There was no statistically significant impact at a significant level $(\alpha \leq 0.05)$ of client capital on earnings per share in ASE banks.

\subsection{Study Objectives}

Subject research seeks to realize a set of outcomes that can be summarized as follows:

1-Knowing whether there is an effect of intellectual capital on the performance of ASE banks.

2-Knowing if there was an effect of human capital on the financial performance of ASE banks.

3-Knowing if there was an effect of structural capital on the financial performance of ASE banks.

4-Knowing if there was an effect of client capital on the financial performance of ASE banks.

\section{Study Limits:}

1- Spatial boundaries: The study was conducted on ASE Commercial banks.

2-Temporal boundaries: The study period was (2012-2018).

\section{Literature: Intellectual capital:}

\section{Intellectual Capital Theory:}

It proposes the relation between knowledge volume at all the organization sections. Such as the increase of individual, group, and organizational knowledge levels, business outcomes performance will also improve.

Intellectual capital is the result of mental processes that form a set of intangible objects that can be used in economic activity and bring income to its owner (organization), covering the competencies of its people (human capital), the value relating to its relationships (relational capital), and 
everything that is left when the employees go home (structural capital), of which intellectual property (IP) is but one component. It is the sum of everything everybody in a company knows that gives it a competitive edge. It plays a prime role in value creation in present economies and institutions, where institutions in knowledge-based economies are depending on knowledge assets more than tangible assets to upgrade their competitive performances [6].

\section{Intellectual capital improves via:}

-Replacing less-qualified performers with the ones who are higher qualified.

-Investing in the present taskforce to make it a bit stronger via concentrating on activities that will improve the employees to learn new technical and management skills that will modify the organization's intellectual capital.

Stewart had defined intellectual capital as the intellectual substance that includes (knowledge, information, outstanding skills, and experience) that individuals possess in a company and that can be used in order to achieve wealth. The first conference on intellectual capital was held in 1995, and it was aimed at agreeing to find a definition for the term intellectual capital, and to define its elements and methods of calculating it. It was chaired by Edvinsson, the first to preside over a position on intellectual capital, and sought to find ways "to make the hidden value concrete [7].

Al-Taweel, Al-Sammak, and Yunus defined intellectual capital as: a set of cognitive capabilities that are available to the company's workforce that can be used to create original worth that achieves a competitive advantage for the company. From the foregoing, we conclude that the intellectual capital is a real wealth and a valuable definition that can be invested and operated effectively for the benefit of the company, and it is a source of strength in achieving a competitive advantage represented by the expertise, competencies and skills that the company possesses [8].

\section{Components of intellectual capital:}

Researchers had divided intellectual capital into the following components:

1-Human capital: It is an important element as it is the essential driver of knowledge, skills and creativity to create value for intangible assets represented by the workforce that is characterized by capacity and innovation. It is defined as the skills, knowledge and experience of workers that enable them to possess the ability and leadership skills in making decisions and solving problems and dealing with exceptional circumstances. It reflects the effectiveness of companies in managing intangible resources to achieve a competitive advantage and create added value for companies [9].

2-Structural capital: It is a special and critical componant of intangible capital. It is the supportive basic structure that aids the organization parts function in continuous measurable procedures. This structure is usually owned by the institution and belongs to it. It is composed of: processes, data, systems, designs, and knowledge. Some structural capital may qualify for official guaratees as intellectual property such as patents, trademarks, copyrights and trade secrets. It is also defined as: Everything that supports the workforce in performing such as corporate business relationships, databases, patents, business networks, etc., as well as representing the intangible aspect of the company's assets [10].

3 -Customer Capital: It is the pillar of human capital, as it includes the vision of the company, the quality and technology of the information systems used and its accessibility. It also expresses the organizational structure and depends on flexibility in the distribution of human capital to the appropriate centers, roles and responsibilities.

Researcher Mention had defined it as everything related to companies and their relationship with external parties, including suppliers, customers, government, distribution channels, investors, the value derived from these relationships and the degree of satisfaction and loyalty with the products and 
services offered by companies to meet the desires and needs of customers [11].

4- Business capital: it is the organizations relationships with their main agents connected with their basic business processes. It consists of:

1- Relationships with customers relations with different customers levels.

2- Relationships with different suppliers of needed resources for the prime business operations.

3- Relationship with shareholders, organizations, and investor that form the market in which the institution deals with.

4- Relationship with allies at which collaboration agreements are maintained at certain intensity levels with other organizations.

5- Relationship with competitors in the same industry sector as well as other related sectors.

6- Relationships with quality improvement and promotion institutions with the aim of improving the key issues in managing the entire company.

5-Social capital: It is the "sum of current and potential resources presented in, available in, and derived from the network of relations possessed by individuals or social unites". It includes the relationship, attitudes, and value that manage interactions among and contribute to economic and social development in society. Social capital is a major value added in organization and it is based on social networks, informal relation, formal relation and trust.

6-Technological capital: It is the role related to knowledge -based economy. It is a combination knowledge that is related to the development and technical system of an organization. It consists of information technology, knowledge research development, and protection rights.

- 7-Spiritual Capital: It is an "intangible knowledge, faith and emotions embedded in the minds of individuals and organizations which includes vision, direction, guidance, principles, value and culture". It consisted of: forgiveness, integrity, empathy, faith, kindness, happiness and honesty [12].

\section{The importance of intellectual capital}

It appears to be a highly important source of wealth and supportive power in companies, and due to the nature of scientific challenges and globalization, the importance of intangible assets had increased and became the largest proportion of the company's assets and advanced intellectual capabilities were among the most important means that companies rely on to attain a competitive advantage for them. The importance of intellectual capital in companies is represented by the following:

1-It is considered a basic and competitive weapon in companies today. Intellectual assets represent the real strength that guarantees their continuity and survival.

2-It is one of the most prominent indicators that reflect the intellectual development of departments, which is considered an important management accounting practice.

3-It provides originative and share ideas that aid to developing companies' performance and creating a competitive advantage for them.

4-It is considered as one of the main topics of human resources and focuses on working individuals who possess special skills and knowledge and the importance of investing them to increase creativity and reduce costs. Intellectual capital is a source of wealth generation in companies and is represented by its added value that is derived from the definition [13]. 


\section{Intellectual Capital Measurement:}

In light of the rapid technological and knowledge development, the usefulness of measuring intellectual capital appears to convince administrators and owners to use intellectual capital to calculate the value of knowledge and to show its role in creating wealth [14].

There were many researchers who had made attempts to measure intellectual capital via building measuring models to benefit from it in developing the competitive advantage and maximizing the company's profits, and some of these models are:

\section{A-Financial Metrics:}

1-Cost model: It is a method based on the (ABC) cost accounting system based on activity and widely adopted in management and accounting. This model was based on the calculating the market value of the defined knowledge in case we want to reach a clear and correct understanding of it, and that the market value of the identifier present with individuals was one of the special measures of the value of their defined knowledge.

2-Market value model: This model was based on defining both the market value and the book value of a company and the comparison between them and considering the market value as the true value that expresses the company's tangible and intangible assets, which is an easy to apply and account value [15].

3-Economic value-added model: This model was based on the settlement of the correct profit of the company with the expenses associated with intangible assets. Changes in the economic value added are considered an indication that it is a resource for a company or not [15].

4-Defined Capital Revenue Model: This model was based on calculating the revenue from the defined capital as a percentage of the company's regular revenue and dividing by the expected revenue from cash assets [16].

5-Human Resources Accounting Cost Model: This model was based on the costs related to human resources by measuring the hidden impact of them through which profits can be achieved, and the intellectual capital is calculated according to this method by dividing the contribution of the human resource on the expenses of the beneficiaries' salaries [15].

6-Calculated value of intangible assets model: This model was based on calculating the additional return from fixed assets, and these numbers are used in determining the ratio of return to intangible assets. Investing on identifiable assets [17].

7-The Intellectual Capital Value-Added Coefficient Model: This model was based on measuring the amount of physical capital used ainnaddition to intellectual capital by creating value for how it was used efficiently, and was based on three main elements: human, physical, and structural capitals; the researchers believed that this model was the optimal measure in calculating the value of intellectual capital, so it had been relied upon in measuring the variables of this study [18].

\section{B-Financial Performance}

Good financial performance is achieved by developing the capabilities and energies available to the company that contribute to increasing the company's ability to deal properly with the industry environment and help ensure that operations are executed efficiently, thus gaining the advantages of competitive financial performance. Financial performance reflects the company's financial position, and describes the methods that are used to reach this position by studying a set of variables such as revenues, sales, assets, liabilities and net income. Companies usually express their financial performance in terms that represent the objective vision of the performance through concrete formulas with numerical and quantitative values.

Financial Performance Concept: It is the ability ability to achieve the goals set, the optimal use of available resources, the achieved return, and the comparison of actual performance results with the expected performance, so it refers to the degree to 
which it is possible to reach the desired goal [19].

The financial performance is based on two main elements:

1-Effectiveness: The performance in the best possible way by reducing the resources used, whether material or immaterial, and reducing time and effort.

2-Competence: It is the ability to reach the achievement of pre-planned goals and see the expected results in reality [20].

\section{Importance of Financial Performance:}

It is derived from following up the work of institutions, testing their behaviors, as well as assessing their conditions, measuring their performance levels and effectiveness, and directing performance towards the required direction by identifying the negatives and their causes, proposing corrective measures and rationalizing public uses. For companies and their investment fields according to their specific objectives, which contribute to making sound decisions to maintain the existance and competition.

[21].

The monetary performance of banks is a tool to:

1-Stimulate investment decisions and directing investors towards commercial banks [22].

2 - remedy the voids, problems and hurdels that may hinder the bank's march [22].

3- Elaborate the current financial position of the bank at specified moments, as a whole, or for a specific portion of the bank's performance or the effectiveness of its shares in the stock market on certain days and periods [23].

4- Motivate the bank's taskforce to use more effort in order to achieve better outcomes and performance levels than its predecessor based on the two basic performance elements [24].

\section{Financial Performance Evaluation Criteria:}

Performance level can be judged according to the following criteria:

1-Historical standard: The level of performance for previous years represents a historical standard. This criterion is effective when judging the level of improvement or deterioration of performance over time.

2-Target: Reflects reasonable levels of performance. Government agencies usually prepare these benchmarks in light of their past experience.

3-Competitive Performance: Government agencies use benchmarks for performance, as they compare actual performance with the performance of one of the company's competitors.

4-The Absolute Standard: These are theoretical standards, such as the standard of zero defects applied by Japanese companies, and it may not be achieved in the application, but it remains a standard that the company seeks to achieve to improve operations [25].

\section{The link between ideological capital and financial outcomes}

This relationship derived its roots from the necessity for business firms in a rapidly changing competitive environment to orient themselves towards evaluating intellectual capital and determining the level of its contribution to explaining the variation in their profitability. The traditional accounting standards alone are no longer able to estimate the real true value of the company by focusing on measuring the value of tangible assets without their identifiable tangible counterparts and the additional expected value they add [26].

\section{Previous Studies:}

1- Al-Radi, 2013, Entitled: The impact of intellectual capital on the performance of tourism offices in Jordan

The research attempted to evaluate the effect of deological capital represented by human, structural, and client capitals on the performance of tourism offices from the point of view of both managers and workers in tourism offices in Jordan

To attain the outcomes of this research, the researcher had used the descriptive and analytical approaches and he used the questionnaire tool. The research sample was a 
set of questionnaires tat were distributed among the companies. Study results revealed that the intellectual capital in the tourism offices was at a medium impact level [27].

2-Al Saleh study, 2015, Entitled: The Impact of Intellectual Capital on Financial Performance in the Jordanian Industrial Companies Listed on the Amman Stock Exchange (ASE).

The research sought the impact of ideological capital on the industrial companies' financial performance, to clarify this concept, its dimensions, and its importance for ASE industrial companies. In order to achieve these objectives, the researcher relied on the descriptive format via using the data, financial reports published for the industrial companies for 2009-2013 period. The study sample was (40) industrial companies.

Study results showed the existence of a positive impact of ideological capital on the performance of the studied indicators, with the exception of the return on property rights index, which showed a negative impact due to the low return on property rights in the study sample [28].

3- Holienka \& Pilková study, 2014, Entitled: Impact of Intellectual Capital and its Components on Firm Performance Before and After 2008 Crisis

This study aimed to clarify the link between intellectual capital and its various ingredients and the companies outputs prior 2008 economic crisis.

Researcher had relied on the financial data of small and medium companies operating in (10) different industrial departments of the State of Slovakia for the years (2008-2011), where the financial data portrayed the situation prior 2008 crisis, and the financial data of (2011), the researcher had used descriptive analysis and the standard approach in measuring the impact of independent variables on the dependent variable. The most important result was that intellectual capital is a great indicator of assets returns, and that the control variables (financial leverage and company size) had the greatest effect on the return on assets from intellectual capital [29].

4- Bryl, L., and Truskolaski, S., Titled: The intellectual capital effectiveness and enterprises' performance-empirical study of Polish listed companies using VAIC method.

The question of the existence and measurement of intellectual capital (IC) in enterprises is significantly growing in importance in recent years. Theoretical assumptions imply that the high efficiency of IC is positively correlated with the value of the company (measured by MV/BV ratio) and the company's performance, such as return on assets, equity and investments. The aim of the article was to examine the intellectual capital efficiency using the VAIC method and its impact on the market value and the performance of Polish companies listed on the Warsaw Stock Exchange from the IT industry. Empirical studies took into account the time delay, what answered the question of whether and with how long delay effectiveness of the individual components of VAIC (SCE, CEE and HCE) has a statistically significant effect on the value and the company's performance measured by: ROA, ROE, ATO and MV / BV [30].

4- Al-Athamneh study ,2017, Entitled; Intellectual capital and its impact on the institutional performance of Jordanian telecommunications companies.

The research aimed to distiguish the level of intellectual capital and its impact on improving the institutional performance of Jordanian telecommunications companies.

Researcher applied the descriptive and analytical formulas and had used the questionnaire tool. The questionnaire was distributed to individuals working in the northern region branches of Jordanian telecommunications companies. The number of questionnaires were (262).

The researcher also conducted a number of statistical tests by extracting arithmetic average, standard deviations and multiple regression. 
Research results pointed out that the level of intellectual capital and the level of institutional performance in telecommunications companies from the point of view of workers in the branches of the northern region was average, and that there is an effect of ideological capital on the performance of these institutions [31].

5- Al Aleemat study ,2019, Entitled: The effect of intellectual capital on the use of modern management accounting techniques in the Jordanian industrial public jointstock companies

This study aimed to demonstrate the impact of intellectual capital on the use of modern accounting techniques in public joint-stock companies and its dimensions represented by human capital, structural capital, and customer capital. The researcher used the descriptive approach and had distributed (300) questionnaires to a sample of public shareholding industrial companies. Study results revealed the existence of a positive impact of intellectual capital of both human, structural, and customer dimensions, on the use of modern accounting techniques in industrial public joint-stock companies [32].

6- ANETA ZEMÁNKOVÁ (2019) titled: Artificial Intelligence and Blockchain in Audit and Accounting: Literature Review

The main objective of presnt study is to initiate the use of artificial intelligence in auditing and accounting, with the concentration on recent technology. The most practical objective of the study was to evaluate the applications and auditing tools advanced and renewed by Biggest companies in audit and accounting. Prime study outcomes include new approaches of auditting proving the importance of artificial intelligence in auditting, especially higher efficiency and reduced errors [33].

7- Katarina Ćurko, Vesna Bosilj Vukšić, Zvonko Merkaš, 2016, titled: Application of Business Intelligence Technology in Croatian Companies: Preliminary Research and Case Study
The main objective of the research was to give an overview of the business intelligence technologies, presenting the outcomes of the basic researches on the use of business intelligence technologies as a means to support management system in newly established companies and state of information systems and in data processing in decision-making of businesses [34].

8- Ali Abid Abojassim Al-Hamidawi, 2014, titled: Assessment of Radiation Hazard Indices and Excess Life time Cancer Risk due to Dust Storm for Al-Najaf, Iraq

Subject research investigated the existance of long-lived gamma radiation in dust storms, and figured the radiation hazard. The dust samples were collected from the Iraqi weather of the year 2013. The average value of the radium element spray was equivalent was $(52.994 \pm 13.041) \mathrm{Bg} / \mathrm{Kg}$, while the average values of:

the external hazard index, internal hazard index, representative level index, absorbed dose in air and annual effective dose in outdoor were $(0.224 \pm 0.0569),(0.201 \pm 0.057)$, $(0.202 \pm 0.048), \quad(26.384 \pm 6.263) \mathrm{nGy} / \mathrm{h}$ and $(0.0324 \pm 0.007185) \mathrm{mSv} / \mathrm{y}$ respectively. The range value of the Excess Lifetime Cancer Risk ranged between (0.0762194) $(0.144037637) \quad$ with average $(0.1132494 \pm 0.025147)$. The Radiation Hazard Indices and Excess Lifetime Cancer Risk had matched the reported international level [35].

\section{Study Methodology}

\subsection{Research Method}

The researcher relied on the following research methods

-Descriptive approach: To refer to previous studies and literatures related to the theoretical framework and to study subject.

-Analytical method: Study data were analyzed via using appropriate statistical and analytical equations for the research subject and test hypotheses, depending on study model. 


\subsection{Study Group and Sample}

The study population consists of banks listed on the Amman Stock Exchange in order to achieve homogeneity of single sector data. The study sample was selected for 15 banks listed on the Amman Stock Exchange and the study period was between 2012-2018.

\subsection{Sources of data collection}

All required data on the subject of the study were extracted from the following resources:

\section{Primary resources:}

It consists from published financial reports along with mathematical equations related to the research topic will be used to obtain information from the published financial statements.

\section{Secondary Sources:}

Using books and references pertaining the research topic, as well as letters and scientific researches, and pamphlets published on ASE.

\subsection{Study variables:}

First: Independent variables and their mathematical formulas

-Intellectual capital $=$ Operating Profit + Salary and Wage Expenses + Depreciation

-Human capital = value added $/$ Expenses (salaries and wages)

-Structural capital $=($ Value Added - Salary

Expenses and Wages)/ Value Added

-Customer capital $=$ book value of total tangible assets $=$ value added $/$ Client capital. [18].

\section{Second: Dependent Variables}

-Return on Assets $(\mathrm{ROA})=$ Net income / Average total assets

Return on Equity $(\mathrm{ROE})=($ Net Income Dividends of Preferred Stock)/ Average Equity of Common Stocks

-Earnings Per Share $(\mathrm{EPS})=($ Net income Dividends of preferred stock)/ Weighted average of common shares.

\subsection{The statistical methods used in the study}

1-Descriptive Statistics: arithmetic mean, standard deviations, highest and lowest values 2-Kolmogorov-Smirnov analysis test: to test the normal distribution of the study variables 3-Multicollinearity test: to find out the existence of a multiple correlation problem 4-Autocorrelation test: to find out the existence of a self-correlation problem.

5-Multiple regression models: to test the study hypotheses, multiple regression models used for the study are:

$$
\begin{aligned}
& \text { ROAi-t }=\beta 0 i-t+\beta 1 * I C i-t+\beta 2 * H C i-t+\beta 3 \\
& * S C i-t+\beta 4 * E C i-t+i-t \\
& R O E i-t=\beta 0 i-t+\beta 1 * I C i-t+\beta 2 * H C i-t+\beta 3 \\
& * S C i-t+\beta 4 * E C i-t+i-t \\
& \text { EPSi-t }=\beta 0 i-t+\beta 1 * I C i-t+\beta 2 * H C i-t+3 * \\
& \text { SCi-t }+\beta 4 * E C i-t+i-t, \text { where: }
\end{aligned}
$$

ROAi- $\mathrm{t}=$ the dependent variable in the first model: return on assets for company $i$ in year $t$ ROEi- $\mathrm{t}=$ the dependent variable in the second model: return on equity for firm $i$ in year $t$

EPSi- $t=$ the dependent variable in the third model: earnings per share of company $i$ in year $\mathrm{t}$

ICi-t $=$ First Independent Variable: The intellectual capital of company $i$ in year $t$

HCi- $t=$ The second independent variable: the human capital of firm $i$ in year $t$

SCi- $\mathrm{t}=$ Third Independent Variable: Structural capital of company $i$ in year $t$

ECi- $t=$ Fourth independent variable: the client capital of company $i$ in year $t$

$\varepsilon i-\mathrm{t}=$ Margin of error for firm $\mathrm{i}$ in year $\mathrm{t}, \beta 0=$ equation constant, $\beta 2, \beta 3, \beta 4$ the regression coefficients of the independent variables.

\section{Study Results}

\subsection{Statistical analysis of the study variables}

The following is a review of this descriptive statistics of the parameters of the whole study sample represented by (112) views from commercial and Islamic banks listed on ASE within the period of the study: 
Table 6.1: Statistical analysis of the study variables

\begin{tabular}{|l|l|l|l|l|}
\hline Variable & $\begin{array}{l}\text { Leas } \\
\mathrm{t} \\
\text { Valu } \\
\mathrm{e}\end{array}$ & $\begin{array}{l}\text { Highe } \\
\text { st } \\
\text { Value }\end{array}$ & $\begin{array}{l}\text { Arithme } \\
\text { tic mean }\end{array}$ & $\begin{array}{l}\text { Stndare } \\
\mathrm{d} \\
\text { Deviati } \\
\text { on }\end{array}$ \\
\hline $\begin{array}{l}\text { Intellect } \\
\text { ual } \\
\text { Capital } \\
\text { Logarith } \\
\mathrm{m}\end{array}$ & 6.98 & 8.92 & 7.80 & 0.41 \\
\hline $\begin{array}{l}\text { Human } \\
\text { Capital }\end{array}$ & 1.32 & 4.37 & 2.89 & 0.68 \\
\hline $\begin{array}{l}\text { Structura } \\
\text { l Capital }\end{array}$ & 0.24 & 0.77 & 0.63 & 0.11 \\
\hline $\begin{array}{l}\text { Client } \\
\text { Capital }\end{array}$ & 1.21 & 164.6 & 7.89 & 25.94 \\
\hline $\begin{array}{l}\text { Return } \\
\text { on } \\
\text { Assets }\end{array}$ & 0.05 & 52.18 & 2.71 & 8.06 \\
\hline $\begin{array}{l}\text { Return } \\
\text { on } \\
\text { Equity }\end{array}$ & 1.14 & 17.66 & 9.21 & 3.73 \\
\hline $\begin{array}{l}\text { Earnings } \\
\text { Per } \\
\text { Share }\end{array}$ & 0.01 & 2.08 & 0.24 & 0.30 \\
\hline
\end{tabular}

It is noticed from the above table that the study variables are not naturally distributed except for the independent variable represented by human capital, and the dependent variable returning on property rights, where the significance value is greater than $5 \%$, which means that the study data are not normaly distributed, and since the sample size is large, as the number of Views (112), the problem of not distributing the data naturally will not affect the validity of the study models.

\subsection{Normal Distribution Test}

The study used the normal distribution test for independent and dependent variables in the study, where the researcher used the Kolmogorov-Smirnov and Shapiro-Wilk test as the rule states that the study variables follow the normal distribution if the significance is greater than 5\% [36].

Table (6.2): Normal Distribution Test

\begin{tabular}{|l|l|l|l|l|}
\hline \multirow{2}{*}{ Variable } & \multicolumn{2}{|l|}{ Shapiro-Wilk } & \multicolumn{2}{l|}{$\begin{array}{l}\text { Kolmogorov- } \\
\text { Smirnova }\end{array}$} \\
\cline { 2 - 5 } & Sig. & $\begin{array}{l}\text { Statisti } \\
\text { c }\end{array}$ & Sig. & $\begin{array}{l}\text { Statisti } \\
\text { c }\end{array}$ \\
\hline $\begin{array}{l}\text { Intellectua } \\
\text { 1 Capital } \\
\text { Logarithm }\end{array}$ & $\mathbf{0 . 0 0}$ & $\mathbf{1 . 9 5 7}$ & $\begin{array}{l}\mathbf{0 . 0 0} \\
\mathbf{1}\end{array}$ & $\mathbf{0 . 1 1 7}$ \\
\hline $\begin{array}{l}\text { Human } \\
\text { Capital }\end{array}$ & $\begin{array}{l}\mathbf{0 . 3 5} \\
\mathbf{1}\end{array}$ & $\mathbf{0 . 9 8 7}$ & $\begin{array}{l}\mathbf{0 . 1 7} \\
\mathbf{3}\end{array}$ & $\mathbf{0 . 0 7 4}$ \\
\hline $\begin{array}{l}\text { Structural } \\
\text { Capital }\end{array}$ & $\begin{array}{l}\mathbf{0 . 0 0} \\
\mathbf{0}\end{array}$ & $\mathbf{0 . 8 6 6}$ & $\begin{array}{l}\mathbf{0 . 0 0} \\
\mathbf{0}\end{array}$ & $\mathbf{0 . 1 8}$ \\
\hline $\begin{array}{l}\text { Client } \\
\text { Capital }\end{array}$ & $\begin{array}{l}\mathbf{0 . 0 0} \\
\mathbf{0}\end{array}$ & $\mathbf{0 . 2 0 7}$ & $\begin{array}{l}\mathbf{0 . 0 0} \\
\mathbf{0}\end{array}$ & $\mathbf{0 . 5 1 5}$ \\
\hline $\begin{array}{l}\text { Return on } \\
\text { Assets }\end{array}$ & $\begin{array}{l}\mathbf{0 . 0 0} \\
\mathbf{0}\end{array}$ & $\mathbf{0 . 2 3}$ & $\begin{array}{l}\mathbf{0 . 0 0} \\
\mathbf{0}\end{array}$ & $\mathbf{0 . 4 9 7}$ \\
\hline $\begin{array}{l}\text { Return on } \\
\text { Equity }\end{array}$ & $\begin{array}{l}\mathbf{0 . 2 0} \\
\mathbf{1}\end{array}$ & $\mathbf{0 . 9 8 4}$ & $\mathbf{0 . 1 7}$ & $\mathbf{0 . 0 7 4}$ \\
\hline $\begin{array}{l}\text { Earnings } \\
\text { Per Share }\end{array}$ & $\begin{array}{l}\mathbf{0 . 0 0} \\
\mathbf{0}\end{array}$ & $\mathbf{0 . 5 5 1}$ & $\begin{array}{l}\mathbf{0 . 0 0} \\
\mathbf{0}\end{array}$ & $\mathbf{0 . 2 1 9}$ \\
\hline
\end{tabular}

It is noticed from the above table that not all study variables were normally distributed, both Shapiro-Wilk and KolmogorovSmirnova studies revealed that:

1- Study Variables: Intellectual capital, structural capital, customer capital, return on assets, and earnings per share are not normally distributed as their significance value was less than $5 \%$.

2-Study Variables: human capital, return on property rights, where the significance value is greater than $5 \%$.

This means that the entire study data were not subject to the normal distribution.

However, as the sample size is large, with the number of observations (112), the problem of being not distributing the data normally will not affect the validity of the study models.

\subsection{Multiple Correlation Test}

Multicollinearity is one of the standard teats used to measure the imbalance of some hypotheses represented in the correlation among independent variables. As a result, the occurrence of the multiplicative correlation 
imbalance, the estimates became sensitive to the slight changes in the data, in addition to that the presence of multiple linear extension may lead to a large determination coefficient with no significance of the estimated parameters, as this study used the correlation matrix test to find out the existence of a multiple correlation imbalance.

Table No. (6.3): Multiple correlation test between independent variables

\begin{tabular}{|c|c|c|c|c|}
\hline $\begin{array}{l}\text { Independe } \\
\text { nt } \\
\text { Variables }\end{array}$ & $\begin{array}{l}\text { Ideologic } \\
\text { al Capital } \\
\text { Logarith } \\
\mathrm{m}\end{array}$ & $\begin{array}{l}\text { Huma } \\
\mathrm{n} \\
\text { Capit } \\
\text { al }\end{array}$ & $\begin{array}{l}\text { Structur } \\
\text { al } \\
\text { Capital }\end{array}$ & $\begin{array}{l}\text { Client } \\
\text { Capit } \\
\text { al }\end{array}$ \\
\hline $\begin{array}{l}\text { Intellectua } \\
1 \quad \text { Capital } \\
\text { Logarithm }\end{array}$ & 1 & --- & --- & ----- \\
\hline $\begin{array}{l}\text { Human } \\
\text { Capital }\end{array}$ & 0.325 & 1 & --- & ----- \\
\hline $\begin{array}{l}\text { Structural } \\
\text { Capital }\end{array}$ & 387 & 0.647 & 1 & ----- \\
\hline $\begin{array}{l}\text { Client } \\
\text { Capital }\end{array}$ & 0.083 & $\overline{-} 0.003$ & 0.039 & 1 \\
\hline
\end{tabular}

Above table showed that the greatest correlation between the independent variables (human capital and structural capital) is (0.647), and this indicated the absence of the phenomenon of multiplicative linear correlation between these independent variables, as the values of the correlation coefficient were all less than (80\%). This is an indication that the sample did not suffer from the high multiple linear correlation problem of the independent variables [36].

\subsection{Self-Correlation Test}

The existence of a self-correlation problem means that an error occurred in one period, and then began to affect the errors of the following periods in a way that leads to the same error being repeated more than once, that is, there may be one error, but it is repeated in all subsequent periods, which leads to the emergence of the limit values The random bound at a level different from the real values, in addition to it may lead to the invalidity of the TF test because the estimated random boundary variance is biased downward, and therefore the estimated value for it is less than the actual value of the random term variance [37].

Table 6.4:
Autocorrelation Test
\begin{tabular}{|l|l|l|l|}
\hline Study & ROA & ROE & EPS \\
Forms & Model & Model & Model \\
\hline $\begin{array}{l}\text { Durbin- } \\
\text { Watson } \\
\text { Value }\end{array}$ & 1.763 & 1.756 & 1.852 \\
\hline
\end{tabular}

The table showed that Durbin-Watson test indicated that there is no self-correlation between errors, due to the approaching of the test value to 2, which lies in the acceptance of the null hypothesis, i.e., the independence hypothesis.

\subsection{Hypotheses Test Results:}

Table (6.5.1): Outcomes of H-O1 hypothesis test

\begin{tabular}{|l|l|l|l|}
\hline $\begin{array}{l}\text { Independent } \\
\text { Variables }\end{array}$ & $\mathrm{B}$ & $\mathrm{T}$ & Sig. \\
\hline Constant & $\begin{array}{l}- \\
0.449\end{array}$ & -0.18 & 0.857 \\
\hline $\begin{array}{l}\text { Human } \\
\text { Capital }\end{array}$ & 0.393 & 0.653 & 0.515 \\
\hline $\begin{array}{l}\text { Structural } \\
\text { Capital }\end{array}$ & 0.783 & 0.198 & 0.843 \\
\hline $\begin{array}{l}\text { Client } \\
\text { Capital }\end{array}$ & 0.306 & 60.967 & 0.000 \\
\hline
\end{tabular}

$\mathrm{F}=949.621$ The dependent variable: return on assets, $\mathrm{R}^{\wedge} 2=34 \%$, Sig. $=0.000$, 
The outcome of the first principal hypothesis test: HO1:

Above table (VI-5) showed the acceptance of the statistical model and that the study variables are highly consistent with each other, and accordingly the first main null hypothesis was not accepted and the alternate hypothesis was accepted, which is "There was a statistically significant effectimpact at $(\alpha \leq$ 0.05) significance level of ideological capital on the return of ASE listed banks was accepted.

1-The results of the 1st. sub-hypothesis (HO11) are as follows:

Above table shows that $\mathrm{T}=0.653$, and the significance value was $=0.515$, which indicated that there is no effect between human capital and return on assets, thus accepting the null hypothesis that states "There was no significant effect at $(\alpha \leq 0.05)$ significance level of human capital on assets rturns of ASE listed banks".

2- Results of sub-hypothesis (HO1-2) were as follows:

Above table shows that $\mathrm{T}=0.198$, and the significance value was $=0.843$, which indicated that there is no effect between structural capital and return on assets, thus accepting the null hypothesis that states " There was no significant effect at $(\alpha \leq 0.05)$ significance level of structural capital on assets rturns of ASE listed banks".

3- Results of sub-hypothesis (HO1-3) were as follows:

Above table shows that $\mathrm{T}=60.967$, and the significance value was $=0.000$, which indicated that there is no effect between client capital and return on assets, thus accepting the null hypothesis that states "There is no statistically significant effect at $(\alpha \leq 0.05)$ significance level for client capital on the return on assets of ASE listed banks.

Table (6.5.2): Outcomes of the H-O2 hypothesis test

\begin{tabular}{|l|l|l|l|l|}
\hline $\begin{array}{l}\text { Independent } \\
\text { Variables }\end{array}$ & $\mathrm{B}$ & & $\mathrm{T}$ & Sig. \\
\hline Constant & -17.011 & & -3.5 & 0.001 \\
\hline Human & -1.149 & & -0.979 & 0.33 \\
\hline
\end{tabular}

\begin{tabular}{|l|l|l|l|l|}
\hline Capital & & & & \\
\hline $\begin{array}{l}\text { Structural } \\
\text { Capital }\end{array}$ & 29.502 & & 3.831 & 0.000 \\
\hline $\begin{array}{l}\text { Client } \\
\text { Capital }\end{array}$ & -0.004 & & -0.391 & 0.697 \\
\hline
\end{tabular}

The dependent variable: return on equity, $\mathrm{R}^{\wedge} 2=51 \%$, Sig. $=0.000, \mathrm{~F}=28.083$

The results of the 2nd main hypothesis test: $\mathrm{HO}$ :

Above table (VI-5-2) showed the acceptance of the statistical model and that the study variables are highly consistent with each other, and accordingly $\mathrm{HO} 2$ null hypothesis is rejected and the alternative one is accepted, that is "There was a statistically significant effect at $(\alpha \leq 0.05)$ significance level of ideological capital on equity returns on ASE listed banks was accepted.

1- Results of the 1st. sub-hypothesis (HO2-1) are as follows:

Above table shows that $\mathrm{T}=-0.979$, and the significance value was $=0.33$, which indicated that there is no effect between human capital and return on assets, thus accepting the null hypothesis that states "There is no statistically significant impact at $(\alpha \leq 0.05)$ significance level for human capital on the return on equity of ASE listed banks.

2- Results of the 2nd. sub-hypothesis (HO1-2) are as follows:

Above table shows that $\mathrm{T}=3.831$, and the significance value was $=0.000$, which indicated that there is no effect between structural capital and return on assets, thus rejecting the null hypothesis and accepting the alternet that states "There is a significant impact at $(\alpha \leq 0.05)$ significance level for structural capital on the equity return of ASE listed banks.

3- Results of the 3rd. sub-hypothesis (HO1-3) are as follows:

Above table shows that $\mathrm{T}=0.391$, and the significance value was $=0.697$, which indicated that there is no effect between client capital and return on assets, thus accepting the null hypothesis that states "There is no significant impact at $(\alpha \leq 0.05)$ significance level for client capital on the return on equity of ASE listed banks. 
Table (6.5.3): Outcomes of H-O3 hypothesis test

\begin{tabular}{|c|c|c|c|}
\hline $\begin{array}{l}\text { Independent } \\
\text { Variables }\end{array}$ & B & $\mathrm{T}$ & Sig. \\
\hline Constant & $-\overline{2.053}$ & -4.648 & 0.000 \\
\hline $\begin{array}{l}\text { Human } \\
\text { Capital }\end{array}$ & 0.404 & 3.79 & 0.000 \\
\hline $\begin{array}{l}\text { Structural } \\
\text { Capital }\end{array}$ & $\begin{array}{l}- \\
1.715\end{array}$ & -2.45 & 0.016 \\
\hline $\begin{array}{l}\text { Client } \\
\text { Capital }\end{array}$ & 0 & $\begin{array}{l}- \\
0.175 \\
\end{array}$ & 0.861 \\
\hline
\end{tabular}

The dependent variable: return onEarnings per share, $\mathrm{R}^{\wedge} 2=36 \%$, Sig. $=0.000, \mathrm{~F}=15.099$

Above table (VI-5-3) showed the acceptance of the statistical model and that the study variables were highly consistent with each other, and accordingly $\mathrm{H}-\mathrm{O} 3$ null hypothesis is rejected and the alternative onewhich states: "There was a statistically significant effect at $(\alpha \leq 0.05)$ significance level of intellectual capital on the return on earnings per share of ASE listed banks was accepted.

1-The results of the 1st. sub-hypothesis (HO3-

1) are as follows:

Above table shows that $\mathrm{T}=-3.79$, and the significance value was $=0.000$, which indicated that there is no impact between human capital and return on assets, thus rejecting $\mathrm{H}-\mathrm{O} 3-1$ and accepting the alternate one that states "There was a significant impact at $(\alpha \leq 0.05)$ significant level for human capital on the earning per share of ASE listed banks.

2- Results of the 2nd. sub-hypothesis (HO3-2) are as follows:

Above table showed that $\mathrm{T}=-2.45$, and the significance value was $=0.016$, which indicated that there was a significant impact of structural capital on earning per share, so, the null hypothesis is rejected and accepting the alternet that states "There was a significant impact at $(\alpha \leq 0.05)$ significance level for structural capital on the earning per share of ASE listed banks.

3- The results of the 3rd. sub-hypothesis (HO1-3) are as follows:

Above table showed that $\mathrm{T}=-0.175$, and the significance value was $=0.861$, which indicated that there was no impact of client capital on the return on assets, thus accepting the null hypothesis that states "There is no statistically significant impact at $(\alpha \leq 0.05)$ significance level for client capital on the return on equity of ASE listed banks.

\section{Study Results and Conclusions:}

7.1. Study Results: the study had revealed the following results:

1-There was no significant impact of human capital on assets yields in

ASE listed banks

2-There was no significant impact of structural capital on assets yields in ASE listed banks.

3-There was a positive significant impact of client capital on the assets yields in ASE listed banks banks, that is, the more the banks increase the clients' capital, the higher the assets return in these banks

4-There was no significant impact of human capital on the equity yields in ASE listed banks.

5-There was a positive effect of statistical significance at a significant level $(\alpha \leq 0.05)$ of structural capital on the equity yields in ASE listed banks.

6-There was no statistically significant impact of client capital on the equity yields in ASE listed banks.

7-There was a positive, statistically significant effect of human capital on the earnings per share of ASE listed banks.

8-There was a statistically significant negative impact of structural capital on the earnings per share in ASE listed banks.

9-There was no statistically significant effect of client capital on earnings per share in ASE listed banks.

\section{Conclusions}

1- All commercial and islamic banks operating in Jordan, are required to adope ideological capital in their operational departments in propper techniques for the sake of inriching their outcomes. 
2- Jordanian banks are urged to train their employees about any new scientific issues and missions in order to develop and obtain new practical experiences

3- Jordanian banks are encoureged to attract employees with updated banking issues, competencies, and experiences.

4-Banks should provide and conduct more future studies related to intellectual capital and its impact on financial performance through the inclusion of new variables.

\section{References}

[1]- Pulic, Ante (2000). VAIC ${ }^{\mathrm{TM}}$ an accounting tool for IC management. International Journal of Technology Management, Volume 20, Number 5, Pages 702-714.

[2]- Al-Mafraji, A., Ahmed Ali, S., (2003).

Titled: " Spending on intellectual capital and its impact on the success of industrial companies", Conference of the University of Applied Sciences, University of Applied Sciences, Amman, Jordan.

[3]- Metwally, Essam El Din Mohamed and Ali, Ahmed Salah (2010). "Concept and Models of Accounting Measurement of Intellectual Capital", The 25th Annual Conference, Mansoura University, Mansoura, Egypt.

[4]- Rousan, M. A. and Al-Ajlouni, M. M. (2010). Titled: "The Impact of Intellectual Capital on Jordanian Banks", Damascus University Journal of Economic and Legal Sciences, Volume 26, Issue 2, pages 37-57.

[5]-Al-Azzawi, M. A. (2013). Titled: "Performance Indicators", Al-Zaytoonah University Conference, Al-Zaytoonah University, Amman, Jordan.
[6]- Abdelkader, Nada (2010). "Knowledge Management and its Impact on Intellectual Capital - (An Applied Study in the State Company for Fertilizers Industry / Southern Region)", Journal of Administrative Studies, Volume 3, Issue 2, pages 188-169.

[7]- Stewart, Thomas A. (1997). Intellectual capital: the new wealth of organizations, New York, United States: Doubleday.

[8]-Al-Tawil, A. M., Al-Sammak, B. and Younis, B. (2016). Titled: Intellectual Capital and Guardian Culture, 1st Edition, Amman, Jordan: Dar Al-Jadid for Publishing and Distribution.

- Abu-Radi, S. 2013, titled: Strategic Agility and Its Impact on the Operations Competitive Capabilities in Jordanian Private Hospitals, Master research, Middle EAST University, Amman - Jordan.

[9]- Ashton, Chris \& Morton, Lynne (2005). Managing talent for competitive advantage: taking a systemic approach to talent management. Strategic HR Review, Volume 4, Number 5, Pages 28-31.

[10]- Siala, Hanen Ghorbel \& Moalla, Marwa (2017). The effect of ownership structure on voluntary disclosure of intellectual capital information: the case of Canadian firms. International Journal of Development Research, Volume 7, Number 1, Pages 11,04411,054 . 
[11]- Mention, Anne-Laure (2012). Intellectual capital, innovation and performance: a systematic review of the literature. Business and Economic Research, Volume 2, Number 1, Pages 1-37.

[12]-Mazhar Abbas, 2015: Researc: Intellectual Components, Journal of Technology and Operations Management 10(1), 15-21.

[13]- Jotheer, Saadoun Hammoud and Rabi'awi, Abbas (2015). Intellectual Capital, 1st Edition, Amman, Jordan: Ghaidaa Publishing and Distribution House.

[14]- Chen, Xin, Hiller, Mark, Sancak, Yasemin \& Fuller Margaret T. (2005). Tissuespecific TAFs counteract polycomb to turn on terminal differentiation. Science, Volume 310, Number 5,749, Pages 869-872.

[15]- Stewart, Thomas A. (1997). Intellectual capital: the new wealth of organizations, New York, United States: Doubleday.

[16] Malhotra, Yogesh (2003). Measuring knowledge assets of a nation: knowledge systems for development, New York, United States.

[17]- Lev, Baruch (1997). The old rules no longer apply. Forbes Magazine, Volume 72, Number 13, Pages 34-38.

[18]- Pulic, Ante (2000). VAIC ${ }^{\text {TM an }}$ accounting tool for IC management. International Journal of Technology Management, Volume 20, Number 5, Pages 702-714.
[19]- Kazem, Faik Jawad (2014). "The role of intellectual capital in enhancing the financial performance of a sample of companies contributing to the Iraq Stock Exchange," Journal of Economic and Administrative Sciences, Volume 20, Issue 87, Pages 277-186. [20]- Gottfredson, Ryan K. \& Joo, Harry (2013). Delivering effective performance feedback: The strengths-based approach. Business Horizons, Volume 55, Number 2, Pages 105-111.

[21]-Al-Azzawi, Muhammad Abdel-Wahhab (2013). "Performance Indicators", A1Zaytoonah University Conference, AlZaytoonah University, Amman, Jordan.

[22]- Al-Radi, A.K., (2013). Titled: The impact of intellectual capital on the performance of tourism offices in Jordan. (Unpublished Master Thesis), Middle East University, Amman, Jordan.

[23]-Al-Khatib, M. M., (2010). Titled: Financial Performance and Its Impact on Corporate Stock Returns, Edition 1, Amman, Jordan: Dar Al-Hamid for Publishing and Distribution.

[24]-Akram Alkhatib,2012, titled: Financial Performance of Palestinian Commercial Banks International Journal of Business and Social Science,

[25]-Al-Tabawi, W. A., (2012). Titled: Managing and measuring performance in the Kuwaiti banking industries. (Unpublished PhD thesis), The Hague University, Netherlands. 
[26]- Fathi, Saeed, Farahmand, Shekoofeh \& Khorasani, Mahnaz (2013) Impact of intellectual capital on financial performance. International Journal of Academic Research in Economics and Management Sciences, Volume 2, Number 1, Pages 6-17.

[27]- Al-Radi, Abdel-Rahman Khaled (2013). The impact of intellectual capital on the performance of tourism offices in Jordan. (Unpublished Master Thesis), Middle East University, Amman, Jordan.

[28]-Al-Saleh, Anas Samir Amin (2015). The impact of intellectual capital on the financial performance of the Jordanian industrial companies listed on the Amman Stock Exchange. (Unpublished Master Thesis), Zarqa University, Zarqa, Jordan.

[29]- Holienka, Marian \& Pilková Anna (2014). Impact of intellectual capital and its components on firm performance before and after crisis. Electronic Journal of Knowledge Management, Volume 12, Number 4, Pages 261-272.

[30]- Bryl, L., and Truskolaski, S.,2015 Titled:

The intellectual capital effectiveness and enterprises` performance-empirical study of Polish listed companies using VAIC method.

Joint International Conference, Bari-Italy.

[31]-Al-Athamneh, Muhammad Hussain Ali (2017). Intellectual capital and its impact on the institutional performance of Jordanian telecommunications companies. (Unpublished Master Thesis), Al al-Bayt University, Mafraq, Jordan.
[32]-Alalimat, Sajida Khalil (2019). The impact of intellectual capital on the use of modern management accounting techniques in the Jordanian public joint-stock industrial companies. (Unpublished Master Thesis), Al al-Bayt University, Mafraq, Jordan.

[33]- ANETA ZEMÁNKOVÁ, (2019), titled: Artificial Intelligence and Blockchain in Audit and Accounting: Literature Review, WSEAS TRANSACTIONS on BUSINESS and ECONOMICS.

[34]- Katarina Ćurko, Vesna Bosilj Vukšić, Zvonko Merkaš, 2016, titled: Application of Business Intelligence Technology in Croatian Companies: Preliminary Research and Case Study, WSEAS TRANSACTIONS on BUSINESS and ECONOMICS.

[35]-Ali Abid Abojassim Al-Hamidawi, 2014, titled: Assessment of Radiation Hazard Indices and Excess Life time Cancer Risk due to Dust Storm for Al-Najaf, Iraq. WSEAS TRANSACTIONS on ENVIRONMENT and DEVELOPMENT.

[36]- Gujarati, N.D. (2003) Basic Econometrics. 4th Edition, Tata McGraw-Hill, New Delhi, 748, 807

[37]- Durbin-Watson statistic test.

\section{Creative Commons Attribution License 4.0 (Attribution 4.0 International, CC BY 4.0)}

This article is published under the terms of the Creative Commons Attribution License 4.0

https://creativecommons.org/licenses/by/4.0/deed.en_US 